\title{
Genetic Relatedness and Colinearity of Genomes of Equine Herpesvirus Types 1 and 3
}

\author{
RAYMOND P. BAUMANN, DONNA C. SULLIVAN, JOHN STACZEK, AND DENNIS J. O'CALLAGHAN* \\ Department of Microbiology and Immunology, Louisiana State University Medical Center, Shreveport, Louisiana 71130
}

Received 3 September 1985/Accepted 4 November 1985

\begin{abstract}
The arrangement and location of homologous DNA sequences within the genomes of equine herpesvirus type 1 (EHV-1) and EHV-3 were investigated by using Southern blot hybridization analyses conducted under stringent conditions. Recombinant plasmid libraries comprising 95 and $84 \%$ of the EHV-1 and EHV-3 genomes, respectively, were labeled with ${ }^{32} \mathrm{P}$-deoxynucleotides by nick translation and were used as probes in filter hybridization studies. The DNA homology between the EHV-1 and EHV-3 genomes was dispersed throughout the genomes in a colinear arrangement. Significant hybridization was detected between the EHV-1 short region inverted repeat sequences, which are known to encode immediate early transcripts, and the corresponding EHV-3 inverted repeat sequences. Interestingly, probes derived from the EHV-1 heterogeneous region, which is adjacent to the EHV-1 short region, hybridized strongly to EHV-3 DNA sequences within a similar genomic location, but did not reveal any corresponding heterogeneity within the EHV-3 genome. Our results demonstrated that there is a highly conserved evolutionary relationship between EHV-1 and EHV-3 and provided the foundation for further investigations to determine whether similarities in protein function underpin the genetic relatedness between these two herpesviruses.
\end{abstract}

The equine herpesviruses (EHVs) comprise a group of infectious viral agents which have similar biological and biochemical features but are serologically distinct (21). The properties of the EHVs closely parallel those of the human herpesviruses. Thus, the EHVs display all of the classical characteristics of herpesviruses, including genomic isomerization $(13,39)$, the ability to establish persistent infections $(8,24,29)$, generation of defective interfering particles in culture and in vivo $(2,5,8,11,12)$, the capacity to oncogenically transform cells in vitro, and alpha-beta-gamma gene regulation (6). In recent studies workers in our laboratory have used molecular hybridization techniques to dissect the genetic relationship of EHV type 1 (EHV-1) and EHV-3. Both EHV-1 and EHV-3 have been shown to possess large double-stranded DNA genomes (94 and 96 megadaltons, respectively), each containing one set of identical inverted repeats that results in the generation of two distinct genomic isomers $(13,34,39,44)$. In addition, both EHV-1 and EHV-3 have been shown to be capable of oncogenically transforming LSH hamster embryo cells in vitro $(1,8,23,29,33$; Sullivan et al., manuscript in preparation).

In order to provide a foundation for future studies designed to address the question of whether the EHVs share protein functions and common regulatory pathways, the genetic relatedness between EHV-1 and EHV-3 was explored by using filter hybridization techniques. Previous investigations in which stringent liquid hybridization conditions were used detected a level of total genomic DNA homology of approximately $10 \%$ between EHV-1 and EHV-3 (38). In this paper we describe the results of intergenomic Southern blot hybridization studies in which we used cloned viral restriction enzyme fragments comprising 95 and $84 \%$ of the EHV-1 and EHV-3 genomes, respectively, as probes to identify cross-hybridizing DNA sequences. Our results extend and modify previous preliminary cross-homology data (25) and permit the following conclusions: (i) DNA homology between EHV-1 and EHV-3

\footnotetext{
* Corresponding author.
}

is dispersed throughout both viral genomes and is not sequestered in a limited number of locations; (ii) DNA sequences shared by the two genomes are arranged colinearly; and (iii) homology exists between the EHV-1 heterogeneous region and colinear EHV-3 sequences, but no corresponding heterogeneous banding pattern is present within restriction enzyme digests of EHV-3 DNA.

\section{MATERIALS AND METHODS}

Cells and viruses. EHV-1 strain Kentucky A was grown in L-M suspension cell cultures as described elsewhere $(22,26)$. EHV-1 was passaged at a low multiplicity of infection $(0.005$ PFU per cell). The virus was purified by polyethylene glycol 6000 precipitation of infected cell-free supernatants, followed by several cycles of rate velocity centrifugation in dextran-10 gradients (26). EHV-3 strain Kentucky (4) was grown in adherent equine transitional carcinoma cells as described previously $(1,39)$. Equine transitional carcinoma cells were infected at multiplicity of infection of 0.1 PFU per cell, and nucleocapsids were isolated by the method of Atherton et al. (1).

Isolation of viral DNA. Purified EHV-1 viral particles or EHV-3 nucleocapsids were suspended in TE buffer $(0.01 \mathrm{M}$ Tris hydrochloride, $\mathrm{pH} 7.4,0.001 \mathrm{M}$ EDTA) and treated with sodium dodecyl sulfate (final concentration, $1 \%$ [wt/vol]) and proteinase $\mathrm{K}(100 \mu \mathrm{g} / \mathrm{ml})$ for $2 \mathrm{~h}$ at $37^{\circ} \mathrm{C}(12)$. Following incubation, the DNA was extracted once with $80 \%$ phenol in TE buffer and twice with chloroform-isoamyl alcohol (24:1, $\mathrm{vol} / \mathrm{vol})$. The DNA was precipitated by adding 2.5 volumes of $95 \%$ ethanol and 0.5 volume of $4 \mathrm{M}$ sodium acetate and was incubated at $-70^{\circ} \mathrm{C}$ for $1 \mathrm{~h}$. The DNA was pelleted by centrifugation at $31,000 \times g$ for $30 \mathrm{~min}$ and was suspended in $0.1 \times$ TE buffer.

Cloning of viral DNA restriction enzyme fragments. Cloning of the EHV-1 genome has been described previously (32). Briefly, viral DNAs (EHV-1 or EHV-3) were digested to completion with BamHI, HindIII, EcoRI, or XbaI and shotgun cloned into the appropriate acceptor site in pUC8, 
pUC12 (42), pBR322 (40), or pACYC184 (7). Alternatively, if specific DNA fragments were desired, individual bands were sliced from agarose gels and isolated by the phenol extraction method of Benson (3). After transformation, bacteria (Escherichia coli HB101 or JM83) were selected for the presence of plasmids containing insertions by assaying for antibiotic sensitivity due to insertional inactivation (pBR322 and $\mathrm{pACYC184)}$ or by determining colony color on $\beta$ galactosidase indicator plates (pUC8 and pUC12). Plasmid DNAs were isolated from individual colonies by the minilysate procedure (14) and were screened by minisubmersible gel electrophoresis following restriction endonuclease digestion. Individual clones were expanded into large bacterial growths, and the plasmid DNA was isolated by the lysis boiling technique (14) and ethidium bromide-cesium chloride dibuoyant density centrifugation. All prospective viral insertion clones were confirmed by hybridization to viral DNA genomic digests bound to hybridization filters. In this manner, restriction enzyme fragments comprising $99 \%$ of the EHV-1 genome and $84 \%$ of the EHV-3 genome were cloned. The details of the cloning of the EHV-3 genome will be described elsewhere (Sullivan et al., in preparation).

Restriction enzyme digestion and Southern blot hybridization. Viral DNAs $(1 \mu \mathrm{g})$ were digested to completion with a three- to fivefold excess of the desired restriction endonuclease under the conditions recommended by the supplier (Bethesda Research Laboratories, Inc., Gaithersburg, Md.). The resultant viral genomic DNA digests were electrophoresed through $0.7 \%$ agarose, stained with ethidium bromide $(0.5 \mu \mathrm{g} / \mathrm{ml})$, and photographed in short-wave UV light (35). Gels containing viral DNA fragments were alkali denatured, neutralized, transferred to hybridization membranes (Gene Screen; New England Nuclear Corp., Boston, Mass.) in 1× SSC ( $1 \times \mathrm{SSC}$ is $0.15 \mathrm{M} \mathrm{NaCl}$ plus $0.015 \mathrm{M}$ sodium citrate), and immobilized by baking in vacuo at $80^{\circ} \mathrm{C}$ for $2 \mathrm{~h}$, using the method of Southern (36). All cross-homology hybridization experiments were conducted by using a standardized set of reaction conditions to allow for consistent data interpretation. Filters were prehybridized in a solution containing $4 \times$ SSC, $1 \times$ Denhardt solution $(0.02 \%$ bovine serum albumin, $0.02 \%$ polyvinylpyrrolidone, $0.02 \%$ Ficoll), $0.1 \%$ sodium dodecyl sulfate, $60 \mu \mathrm{g}$ of yeast RNA per ml, and $50 \mu \mathrm{g}$ of denatured salmon sperm DNA per ml for at least $4 \mathrm{~h}$ at $65^{\circ} \mathrm{C}$. Following prehybridization, the filters were hybridized for $72 \mathrm{~h}$ at $65^{\circ} \mathrm{C}$ in the same mixture with $1 \times 10^{6}$ to $2 \times 10^{6} \mathrm{cpm}$ of nick-translated, ${ }^{32}$ P-labeled (28), denatured viral DNA fragments present as insertions in cloning vectors. All probes were sonicated prior to denaturation to generate small DNA fragments of less than 800 base pairs. The filters were washed four times in hybridization buffer $(20 \mathrm{~min}$, $62^{\circ} \mathrm{C}$ ) and then once in $1 \times \mathrm{SSC}-0.1 \%$ sodium dodecyl sulfate ( $20 \mathrm{~min}$ ) and twice in $0.3 \times \mathrm{SSC}-0.1 \%$ sodium dodecyl sulfate (30 min). The filters were air dried and exposed to Kodax $\mathrm{X}$-Omat $\mathrm{AR}$ film at $-70^{\circ} \mathrm{C}$ for $1,4,7$, or 14 days in the presence of $\mathrm{Du}$ Pont Cronex Lightning-Plus intensifying screens.

\section{RESULTS}

Selection of probes and hybridization conditions. The development of genomic libraries of cloned restriction enzyme fragments of both the EHV-1 and EHV-3 genomes enabled us to assess comprehensively the genetic relatedness of all regions of these EHV genomes including unique long terminal DNA sequences present in EHV-1 defective interfering particle DNA, unique long sequences integrated into EHV1-transformed and tumor cell DNAs, inverted repeat se- quences recently shown to encode EHV-1 immediate early mRNA (W. L. Gray et al., manuscript in preparation), and heterogeneous (het) sequences derived from a polymorphic region of the EHV-1 genome.

The decisions to use only cloned viral DNA fragments as probes and to use a standardized set of stringent hybridization conditions which permitted detection of DNA sequences that displayed $23 \%$ or less base pair mismatch (15) for these studies were made for the following reasons: (i) viral restriction enzyme fragments obtained from agarose gels were found to be contaminated with other comigrating fragments, a problem which can be eliminated by using cloned fragments as probes; (ii) the use of stringent hybridization conditions decreased the possibility that any crosshybridization detected was the result of nonspecific annealing, such as association of guanine-cytosine-rich genomic regions; and (iii) under the conditions used (see Materials and Methods), no vector (pUC8, pUC12, pBR322, or pACYC184) hybridization to either EHV-1 or EHV-3 DNA was observed even when excessive amounts of ${ }^{32} \mathrm{P}$-labeled plasmid DNA were incubated with hybridization membranes containing EHV DNA (data not shown).

Hybridizations in which EHV-1 cloned probes were used. As shown in Fig. 1, both the EHV-1 genome and the EHV-3 genome have been mapped with multiple restriction endonucleases $(13,39)$. These two viruses exhibit similar genomic structures, and both contain a single set of inverted repeats which result in a two-isomer structure. In addition, both viruses have recently been shown to be capable of oncogenically transforming hamster embryo cells in culture. The common biological and biochemical properties of these two herpesviruses prompted us to study their relatedness at the DNA level.

An extensive repertoire of cloned EHV-1 restriction enzyme fragments comprising more than $94 \%$ of the EHV-1 genome was isolated (see Materials and Methods) and was used in Southern blot hybridizations to investigate regional genomic homologies with EHV-3 DNA. Individual EHV-1 clones were labeled with ${ }^{32} \mathrm{P}$ by nick translation, denatured, and incubated with filters to which EHV-3 genomic restriction enzyme digests had been bound. As Fig. 2 and 3 show, under stringent hybridization conditions $\left(65^{\circ} \mathrm{C}, 4 \times \mathrm{SSC}\right)$ strong hybridization was observed between virtually all EHV-1 probes and filter-bound EHV-3 restriction enzyme fragments. EHV-1 cloned probes as large as 19.9 megadaltons (XbaI fragment A) (Fig. 3) and as small as 1.3 megadaltons (EcoRI fragment Q) (Fig. 2) hybridized to EHV-3 sequences without any obvious differences attributable to probe size. EHV-1 probes derived from the unique long DNA region hybridized strongly to EHV-3 fragments derived from colinear positions within the EHV-3 genome. For example, EHV-1 cloned fragments $\mathrm{XbaI}-\mathrm{G}(0.01$ to 0.05 map units), XbaI-E (0.38 to 0.44 map units), and EcoRI-F (0.59 to 0.68 map units) hybridized to colinear EHV-3 DNA fragments at map units 0.01 to 0.03 (BamHI-M, BclI-E, BglII-A), at map units 0.33 to 0.44 (BamHI-B and -J; BclI-D and -M; BglII-C), and at map units 0.58 to 0.68 (BamHI-K, $-\mathrm{O},-\mathrm{S}$, and -W; BclI-F and -G;BglII-E, -K, and -N), respectively (Fig. 2 and 3 and Table 1). In addition, EHV-1 cloned fragments from the long region which spanned sequences that are found integrated in EHV-1 oncogenically transformed cells (30) (XbaI-A at 0.44 to 0.65 map units and Bam HI-B at 0.46 to 0.57 map units) hybridized to a colinear position within the EHV-3 genome at 0.48 to 0.55 map units (BamHI-G; BclI-C; BglII-J, -L, and -M) (Fig. 2 and 3). Also, the EHV-1 het region probe (EcoRI fragments K and L) (Fig. 


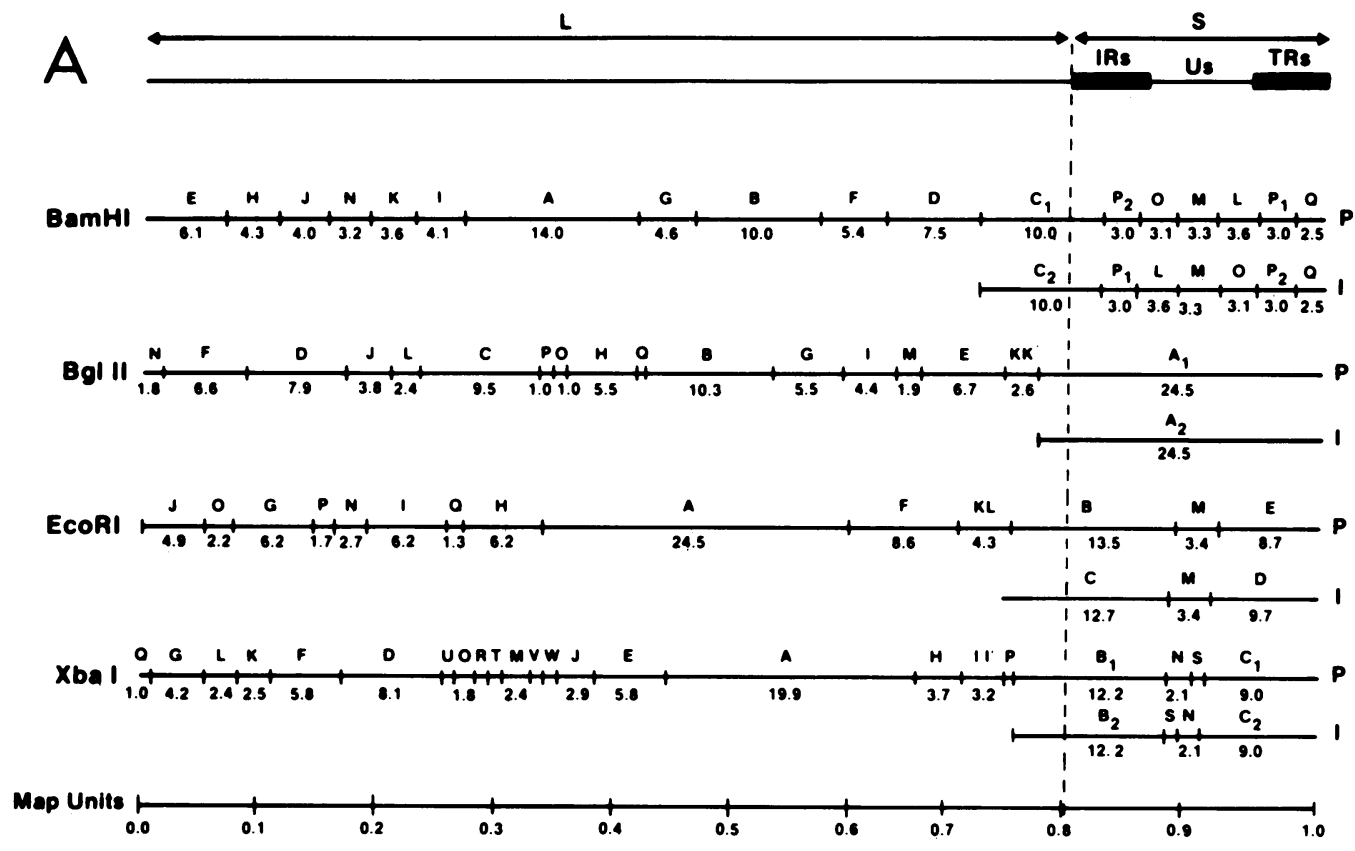

B

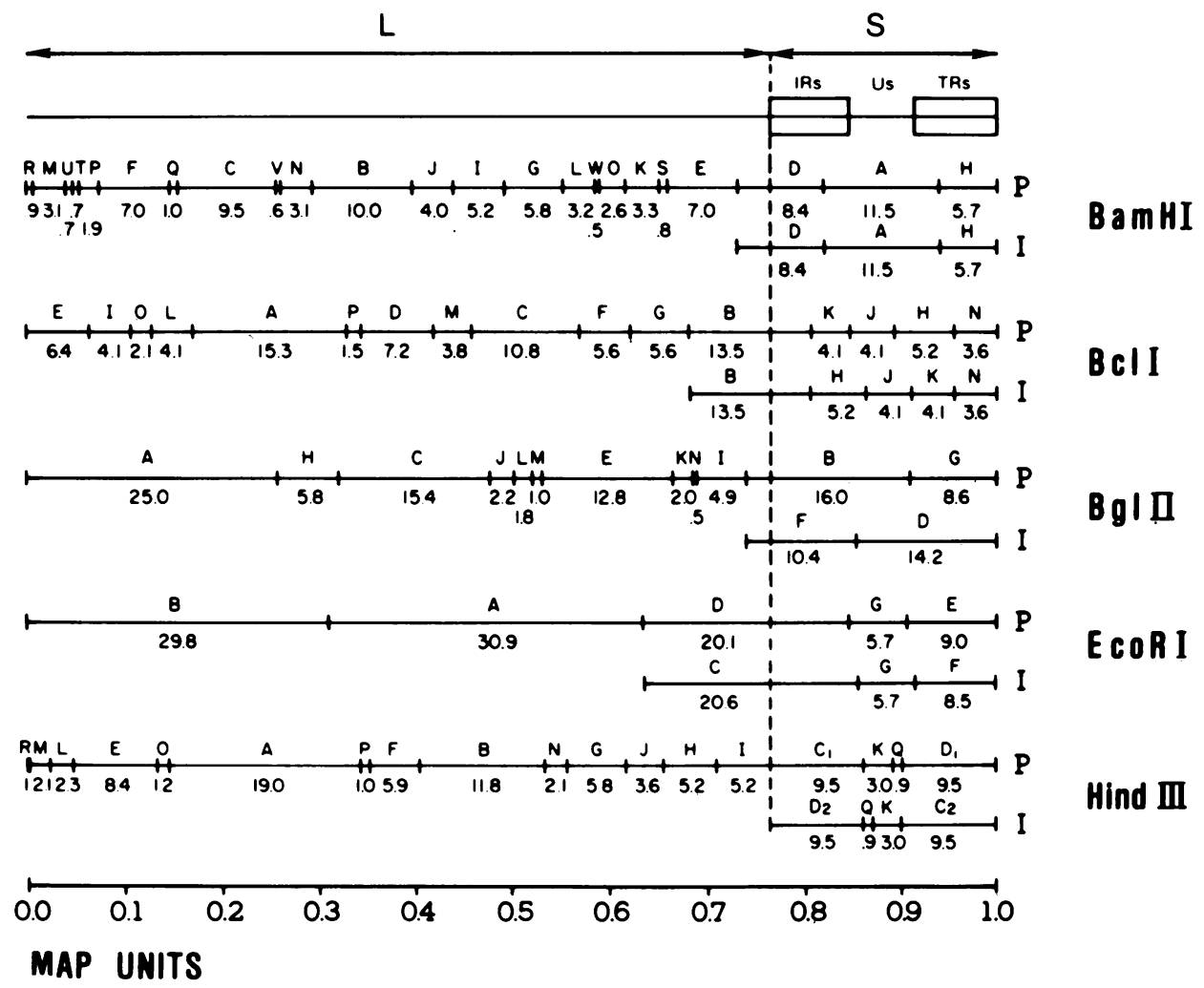

FIG. 1. (A) Restriction endonuclease cleavage maps of the EHV-1 genome. (B) Restriction endonuclease cleavage maps of the EHV-3 genome. Fragment sizes are indicated (in megadaltons). IRs, Inverted repeat sequences; TRs, terminal repeat sequences; L, long region; S, short region. P, Prototype arrangement; I, inverted arrangement. 


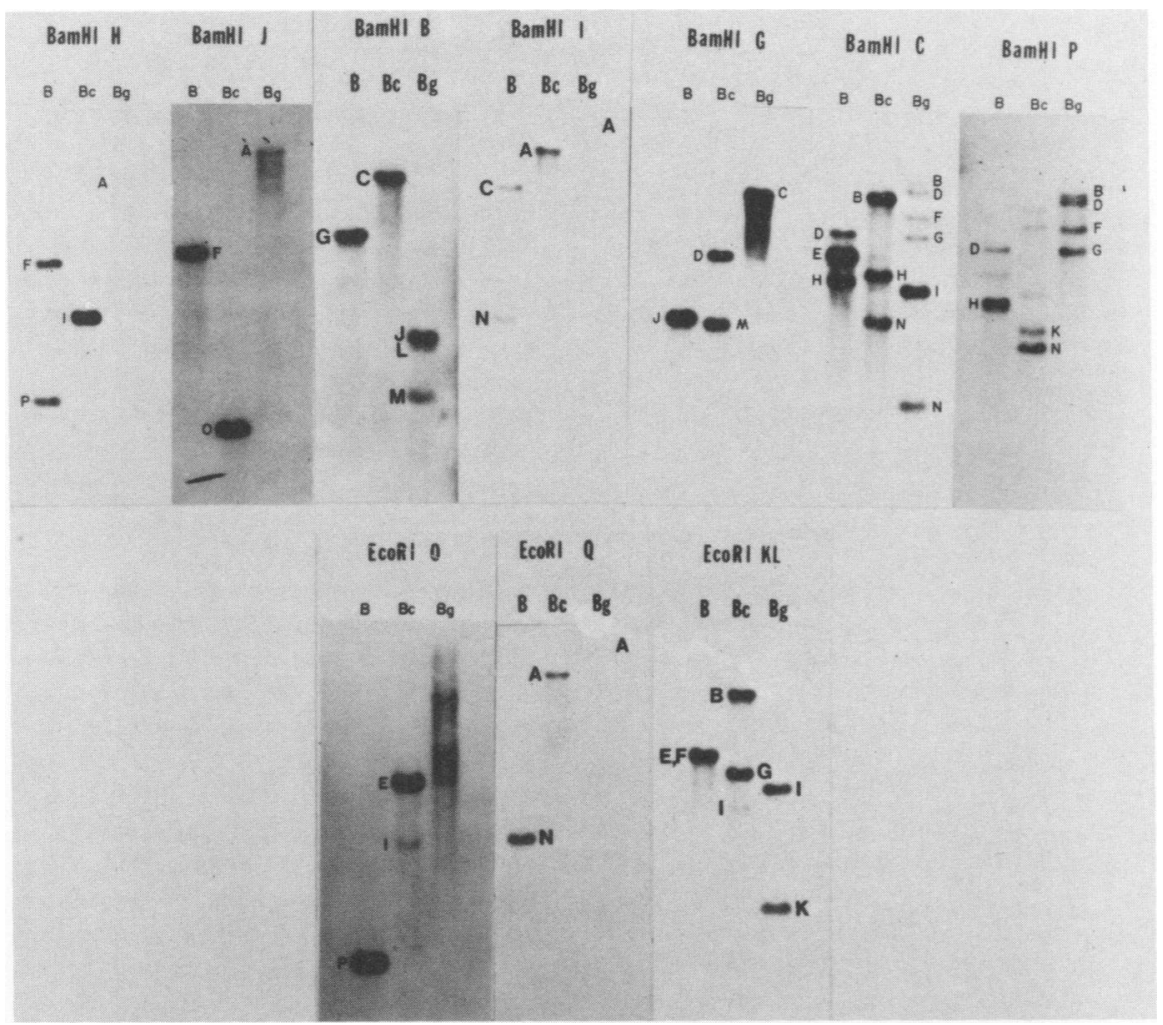

FIG. 2. Blot hybridization analysis of EHV-3 DNA with ${ }^{32}$ P-labeled EHV-1 DNA fragment clones. EHV-1 restriction enzyme fragments present as insertions in plasmid cloning vectors were labeled with ${ }^{32} \mathrm{P}$ by nick translation and hybridized with EHV-3 restriction enzyme $B a m H I(B), B c I I(B c)$, and $B g l I I(B g)$ digests which had been electrophoresed through agarose gels and transferred to Gene Screen. The EHV-1 fragment clone used as the probe is indicated at the top of each filter.

2), which hybridized to a stepladder of submolar bands in EHV-1 digests, hybridized to discrete (molar), colinear EHV-3 fragments (BamHI-E; BclI-B and -G; BglII-I and -K) (Fig. 2 and Table 1), suggesting that no apparent heterogeneity is present in the EHV-3 genome even though homology to the EHV-1 het region exists. In contrast, when an EHV-3 probe (HindIII-H) from a position colinear with the EHV-1 het region was hybridized to an EHV-1 blot, a stepladder of hybridizing bands was apparent (Fig. 4). These observations, as well as the results of our extensive analysis of EHV-3 DNA by restriction enzyme methods, indicated that a polymorphic (heterogeneous) region does not exist within the EHV-3 genome at this position.

EHV-1 cloned fragments from the inverted repeats (BamHI-C at 0.71 to 0.81 map units and BamHI-P at 0.81 to 0.84 map units) hybridized to both EHV-3 inverted repeats, as demonstrated by their hybridization to all four EHV-3 half-molar bands (BgIII-B, -D, -F, and -G) (Fig. 2) which were derived from the short region and are a hallmark of the two-isomer structure of EHV-3. In hybridizations in which we used EHV-1 unique short $\left(U_{s}\right)$ fragment clones as probes (EcoRI-M and BamHI-M) (Fig. 1) and in reciprocal studies in which we used EHV-3 $\mathrm{U}_{\mathrm{s}}$ clones (BamHI-A [Fig. 4], EcoRI-G, HindIII-K, and HindIII-Q [Tables 1 and 2]) we detected no reproducible homology between the $U_{s}$ regions of the EHV-1 and EHV-3 genomes, although occasionally weakly hybridizing bands appeared after prolonged exposure times (data not shown). These data suggested that under the stringent conditions used for these studies, no homology could be detected between EHV-1 and EHV-3 Us DNA sequences, indicating that this genomic region has not been as highly conserved at the DNA level as other unique EHV DNA sequences.

The results of the cross-homology studies in which we used 18 EHV-1 fragment clones as probes against EHV-3 blots are summarized in Table 1. A comparison of the locations (in map units) of the EHV-1 probes with the minimal map positions of the hybridizing EHV-3 bands indicated that in all reactions cross-hybridization occurred at colinear map positions. These results confirmed the results of previous cross-homology studies in which liquid hybridization techniques were used (38) and modified the conclusions of preliminary Southern blot hybridization studies (25) made prior to the refinement of the EHV-1 restriction enzyme map (13) by demonstrating that DNA homology is dispersed throughout the EHV-1 and EHV-3 genomes in a colinear fashion (Fig. 5). Thus, our results support the contention that EHV-1 and EHV-3 are closely related evolutionarily.

Hybridizations in which EHV-3 cloned probes were used. To confirm and extend the information obtained from crosshomology experiments in which EHV-1 probes were used and to generate a more refined overlapping cross-hybridization linkage, EHV-3 restriction enzyme fragments were cloned and used as probes in Southern blot hybridizations under stringent conditions to detect homologous DNA sequences in EHV-1 genomic digests bound to hybridization membranes. These reciprocal hybridization experiments with EHV-3 cloned probes (Fig. 4) confirmed the results of the EHV-1 clone hybridization experiments and demonstrated the following facts: (i) EHV-3 clones harboring unique viral DNA sequences hybridized to EHV-1 DNA 


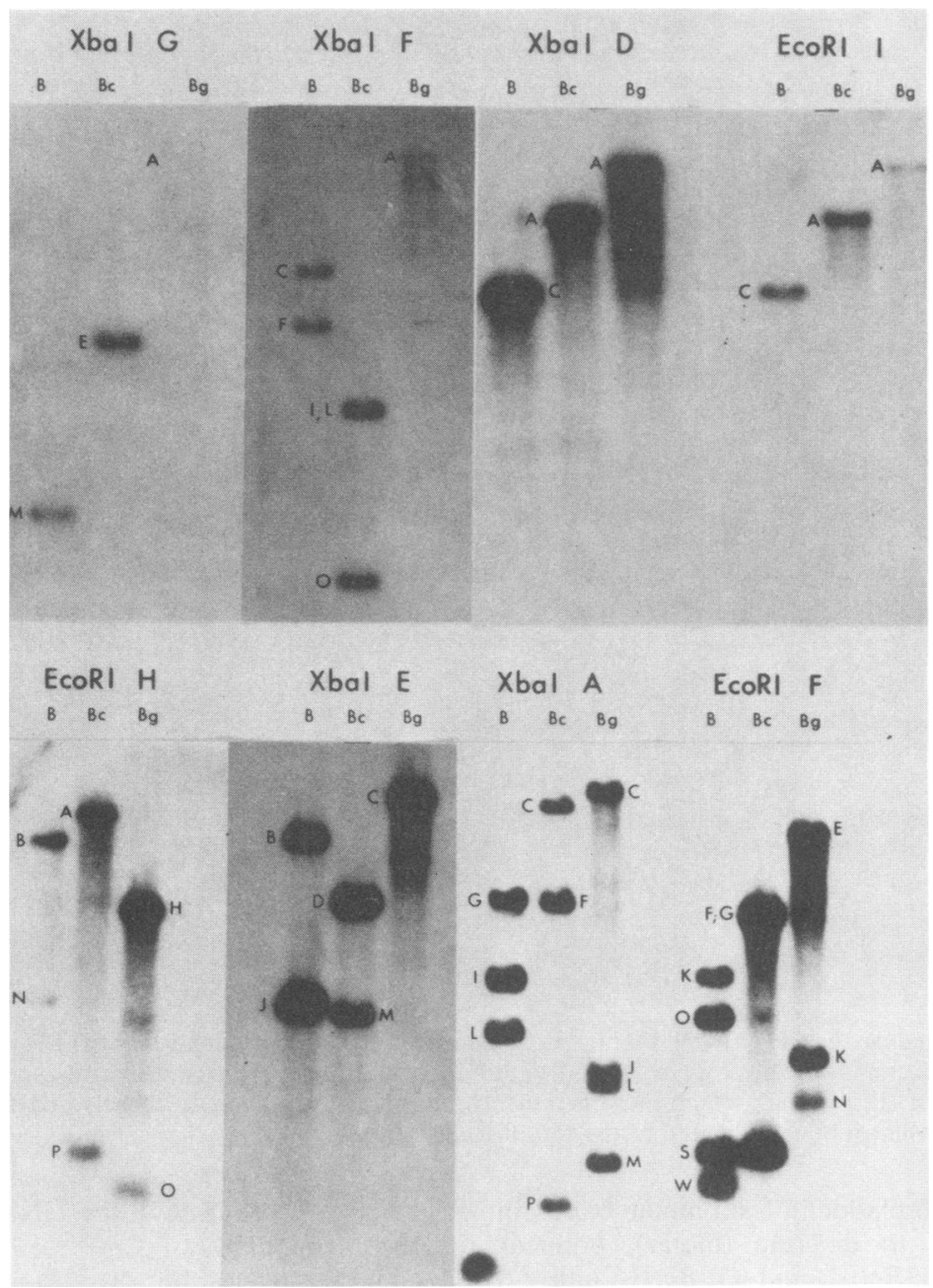

FIG. 3. Blot hybridization analysis of EHV-3 DNA with ${ }^{32}$ P-labeled EHV-1 DNA fragment clones. EHV-1 restriction enzyme fragments present as insertions in plasmid cloning vectors were labeled with ${ }^{32} \mathrm{P}$ by nick translation and hybridized with EHV-3 restriction enzyme $B a m H I(B), B c l I(B c)$, and BglII (Bg) digests bound to filters. The EHV-1 fragment clone used as the probe is indicated at the top of each filter.

fragments at colinear positions; (ii) the homology was dispersed throughout the genome in a colinear fashion; (iii) EHV-3 sequences derived entirely from the $U_{s}$ region failed to hybridize to colinear EHV-1 sequences, as demonstrated by the lack of hybridization between EHV-3 BamHI fragment $A$, which spans the $U_{s}$ region, and EHV-1 $U_{s}$ DNA fragments BamHI-M, EcoRI-M, and XbaI-N (Table 2 and Fig. 4); also see EHV-3 EcoRI-G, HindIII-K, and HindIII-Q hybridization results (Table 2); and (iv) EHV-3 clones containing inverted repeat sequences (BamHI-A and -D) (Fig. 4) hybridized to both EHV-1 inverted repeats (Fig. 5). In addition, EHV-3 cloned probes (BamHI-E, BglII-K, and HindIII-H) (Fig. 4) colinear with the EHV-1 het region hybridized to the stepladder of submolar bands which were derived from the EHV-1 het region. A similar heterogeneous region of submolar fragments has not been found within the EHV-3 genome, although EHV-1 het region probes crosshybridize at a colinear position.

The results of cross-hybridization experiments performed by using 15 cloned EHV-3 fragments as probes are summarized in Table 2. Again, as in Table 1, a comparison of probe map positions with the minimal map positions of hybridizing
EHV-1 bands indicated that in all reactions, hybridization positions mapped to colinear genomic locations. Finally, a diagram incorporating the results obtained from all hybridization experiments with either EHV-1 or EHV-3 cloned fragments as probes is shown in Fig. 5. In this representation, the hybridizing DNA sequences (boxed areas) which are arranged in a colinear fashion produce a diagonal line. As Fig. 5 shows, only probes derived from the EHV-1 and EHV-3 inverted repeats produced hybridization patterns which are offset from the diagonal; this was due to the nature of the inverted repeat sequences, which bracketed the $U_{s}$ segment and thus reflected the two-isomer structure of the viral genomes.

\section{DISCUSSION}

In this paper we describe the results of Southern blot hybridization cross-homology studies in which we used an array of cloned EHV-1 and EHV-3 restriction enzyme fragments; our results indicate that extensive and widely dispersed genomic homology exists between these two viruses. A total of 33 viral fragment clones were used as probes in separate hybridization experiments to generate a 
TABLE 1. EHV-1 cloned probes hybridized to EHV-3 blots

\begin{tabular}{|c|c|c|c|c|c|}
\hline \multirow[b]{2}{*}{ EHV-1 probe ${ }^{a}$} & \multirow{2}{*}{$\begin{array}{l}\text { Location } \\
\text { (map units) }\end{array}$} & \multicolumn{3}{|c|}{ EHV-3 hybridizing bands } & \multirow{2}{*}{$\begin{array}{l}\text { EHV-3 region of homology } \\
\text { (map units) })^{b}\end{array}$} \\
\hline & & $\begin{array}{c}\text { BamHI } \\
\text { fragment(s) }\end{array}$ & $\begin{array}{c}B c l l \\
\text { fragment(s) }\end{array}$ & $\begin{array}{c}B g l \mathrm{II} \\
\text { fragment(s) }\end{array}$ & \\
\hline XbaI-G & $0.011-0.05$ & $\mathbf{M}$ & $\mathrm{E}$ & A & $0.01-0.03$ \\
\hline EcoRI-O & $0.05-0.08$ & $\mathrm{P}$ & E,I & $-c$ & $0.06-0.08$ \\
\hline BamHI-H & $0.06-0.11$ & F,P & I & A & $0.06-0.11$ \\
\hline Bam HI-J & $0.11-0.15$ & $\mathrm{~F}$ & $\mathrm{O}$ & A & $0.11-0.13$ \\
\hline XbaI-F & $0.11-0.17$ & $\mathrm{C}, \mathrm{F}$ & $\mathrm{I}, \mathrm{L}, \mathrm{O}$ & A & $0.08-0.18$ \\
\hline$X b a I-D$ & $0.17-0.25$ & $\mathrm{C}$ & A & A & $0.18-0.25$ \\
\hline EcoRI-I & $0.19-0.25$ & $\mathrm{C}$ & A & A & $0.18-0.25$ \\
\hline BamHI-I & $0.22-0.27$ & $\mathrm{C}, \mathrm{N}$ & A & A & $0.18-0.26$ \\
\hline EcoRI-Q & $0.25-0.27$ & $\mathbf{N}$ & A & A & $0.25-0.30$ \\
\hline EcoRI-H & $0.27-0.32$ & $\mathrm{~B}, \mathrm{~N}$ & $\mathrm{~A}, \mathrm{P}$ & $\mathrm{H}, \mathrm{O}$ & $0.25-0.33$ \\
\hline XbaI-E & $0.38-0.44$ & $\mathrm{~B}, \mathrm{~J}$ & $\mathrm{D}, \mathbf{M}$ & $\mathrm{C}$ & $0.33-0.44$ \\
\hline$X b a I-A$ & $0.44-0.65$ & G,I,L & $\mathrm{C}, \mathrm{F}, \mathrm{P}$ & C,J,L,, $\mathbf{M}$ & $0.44-0.58$ \\
\hline BamHI-G & $0.41-0.46$ & J & $\mathbf{D}, \mathbf{M}$ & C & $0.39-0.43$ \\
\hline Bam HI-B & $0.46-0.57$ & G & $\mathrm{C}$ & J,L,M & $0.48-0.55$ \\
\hline EcoRI-F & $0.59-0.68$ & $\mathrm{~K}, \mathrm{O}, \mathrm{S}, \mathrm{W}$ & F,G & $\mathrm{E}, \mathrm{K}, \mathrm{N}$ & $0.58-0.68$ \\
\hline EcoRI-K and -L & $0.68-0.73$ & E & $B, G$ & $\mathrm{I}, \mathrm{K}$ & $0.67-0.72$ \\
\hline Bam HI-C & $\begin{array}{l}0.70-0.81 \\
0.98-1.0\end{array}$ & $\mathrm{D}, \mathrm{E}, \mathrm{H}$ & $\mathrm{B}, \mathrm{H}, \mathrm{N}$ & $\begin{array}{l}\mathrm{B}, \mathrm{D}, \mathrm{F} \\
\mathrm{G}, \mathrm{I}, \mathrm{N}\end{array}$ & $\begin{array}{l}0.68-0.81 \\
0.94-1.0\end{array}$ \\
\hline BamHI-P & $0.81-0.84$ & $\mathrm{D}, \mathrm{H}$ & $\mathrm{K}, \mathrm{N}$ & $\mathrm{B}, \mathrm{D}, \mathrm{F}, \mathrm{G}$ & $0.80-0.82$ \\
\hline & $0.96-0.93$ & & & & $0.94-1.0$ \\
\hline BamHI-M & $0.87-0.91$ & & & & $\mathrm{ND}^{d}$ \\
\hline EcoRI-M & $0.87-0.91$ & & & & ND \\
\hline
\end{tabular}

${ }^{a}$ EHV-1 BamHI and EcoRI fragments were cloned into plasmid vector pUC8 or pBR322. All Xbal fragments were cloned into pACYC184. The clones are listed in order of increasing map units.

${ }^{b}$ Minimal regions of hybridization, as determined by alignment of hybridization patterns with EHV-3 restriction enzyme maps.

c - , A partial digest which could not be reliably interpreted was present in this lane.

${ }^{d}$ ND, No detectable hybridization under stringent annealing conditions.

cohesive and overlapping linkage of homology among various genomic regions. Furthermore, all hybridization experiments were conducted under stringent annealing conditions, and reciprocal reactions were conducted to confirm that homologous EHV-1 and EHV-3 DNA sequences are ar- ranged in a colinear fashion. Some specific features of the hybridization patterns of selected genomic regions are of note. First, while DNA probes from the EHV-1 het region, hybridized to EHV-3 fragments from a colinear genomic location, they failed to detect a similar heterogeneity within

TABLE 2. EHV-3 cloned probes hybridized to EHV-1 blots

\begin{tabular}{|c|c|c|c|c|c|c|}
\hline \multirow{2}{*}{$\begin{array}{l}\text { EHV-3 } \\
\text { probe }^{a}\end{array}$} & \multirow{2}{*}{$\begin{array}{l}\text { Location } \\
\text { (map units) }\end{array}$} & \multicolumn{4}{|c|}{ EHV-1 hybridizing bands } & \multirow{2}{*}{$\begin{array}{l}\text { EHV-1 region of homology } \\
\text { (map units) })^{b}\end{array}$} \\
\hline & & $\begin{array}{c}\text { BamHI } \\
\text { fragment(s) }\end{array}$ & $\begin{array}{c}B g l \mathrm{II} \\
\text { fragment(s) }\end{array}$ & $\begin{array}{c}E c o R I \\
\text { fragment(s) }\end{array}$ & $\begin{array}{c}X b a I \\
\text { fragment(s) }\end{array}$ & \\
\hline HindIII-E & $0.04-0.13$ & $\mathrm{E}, \mathrm{H}$ & $\mathrm{D}, \mathrm{F}$ & $\mathrm{G}, \mathrm{O}$ & $-^{c}$ & $0.06-0.13$ \\
\hline BamHI-F & $0.08-0.16$ & $\mathbf{J}, \mathbf{K}, \mathbf{N}$ & $\mathrm{D}, \mathrm{J}$ & $\mathrm{G}, \mathrm{N}$ & $\mathrm{D}, \mathrm{F}$ & $0.13-0.22$ \\
\hline BamHI-C & $0.17-0.26$ & $\mathrm{I}, \mathrm{K}, \mathbf{N}$ & $\mathrm{C}, \mathrm{J}$ & $\mathbf{I}, \mathbf{N}$ & - & $0.18-0.27$ \\
\hline BamHI-B & $0.29-0.39$ & A & $\mathrm{C}, \mathrm{H}, \mathrm{P}, \mathrm{O}$ & $\mathrm{A}, \mathrm{H}$ & - & $0.28-0.42$ \\
\hline HindIII-F & $0.35-0.41$ & $A, G$ & $\mathrm{~B}, \mathrm{H}, \mathrm{Q}$ & A & $\mathrm{A}, \mathrm{E}, \mathrm{J}, \mathbf{M}$ & $0.36-0.48$ \\
\hline BamHI-J & $0.39-0.44$ & G & B & A & - & $0.43-0.48$ \\
\hline BamHI-G & $0.49-0.55$ & $\mathbf{B}, \mathbf{F}$ & $\mathrm{B}, \mathrm{G}$ & A & - & $0.48-0.60$ \\
\hline BamHI-L & $0.55-0.59$ & $\mathbf{F}$ & $\mathrm{G}, \mathrm{I}$ & A & A & $0.58-0.61$ \\
\hline BamHI-K & $0.62-0.65$ & D & $\mathbf{E}, \mathbf{M}$ & $\mathbf{F}$ & - & $0.65-0.72$ \\
\hline BamHI-S & $0.65-0.66$ & D & $\mathrm{E}$ & $\mathrm{F}$ & - & $0.68-0.71$ \\
\hline BamHI-E & $0.66-0.73$ & $\mathrm{C}, \mathrm{D}$ & $\mathrm{E}, \mathbf{K}, \mathbf{K}^{\prime}$ & $\mathrm{F}, \mathrm{K}, \mathrm{L}$ & $\mathrm{A}, \mathrm{B}, \mathrm{H}, \mathrm{I}$ & $0.68-0.77$ \\
\hline$B g l I I-K$ & $0.67-0.69$ & D & E & $\mathrm{F}, \mathrm{K}, \mathrm{L}$ & - & $0.68-0.73$ \\
\hline HindIII-H & $0.65-0.71$ & $\mathrm{C}, \mathrm{D}$ & $\mathbf{E}, \mathbf{K}, \mathbf{K}^{\prime}$ & $\mathrm{F}, \mathrm{K}, \mathrm{L}$ & - & $0.68-0.77$ \\
\hline \multirow[t]{2}{*}{ BamHI-D } & $0.73-0.82$, & $\mathrm{C}, \mathrm{Q}$ & A & $\mathrm{B}, \mathrm{C}, \mathrm{D}, \mathrm{E}$ & $B, C$ & $0.78-0.83$ \\
\hline & $0.94-1.00$ & & & & & $0.98-1.00$ \\
\hline BamHI-A & $0.82-0.94$ & $\mathrm{C}, \mathrm{L}, \mathrm{O}, \mathrm{P}$ & A & $\mathrm{B}, \mathrm{C}, \mathrm{D}, \mathrm{E}$ & $\mathrm{B}, \mathrm{C}$ & $\begin{array}{l}0.78-0.88 \\
0.92-0.98\end{array}$ \\
\hline EcoRI-G & $0.85-0.91$ & & & & & $\mathrm{ND}^{d}$ \\
\hline HindIII-K & $0.86-0.89$ & & & & & ND \\
\hline HindIII-Q & $0.86-0.90$ & & & & & ND \\
\hline
\end{tabular}

${ }^{a}$ All EHV-3 fragments were cloned into plasmid vector pUC8 or pBR322. The clones are listed in order of increasing map units.

${ }^{b}$ Minimal regions of hybridization, as determined by alignment of hybridization patterns with EHV-1 restriction enzyme maps (see Fig. 1).

c - Not done.

${ }^{d}$ ND, No detectable hybridization under stringent annealing conditions. 


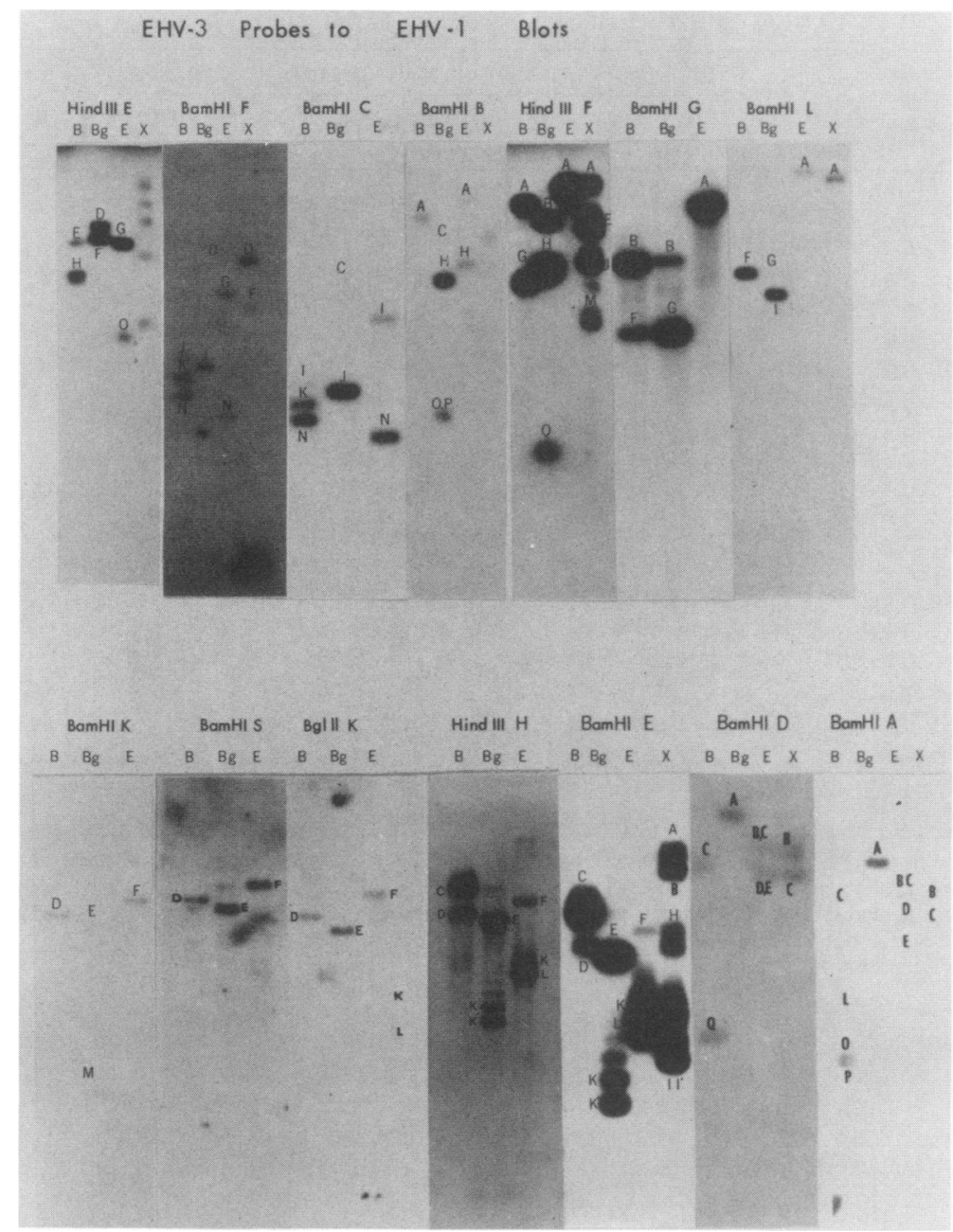

FIG. 4. Blot hybridization analysis of EHV-1 DNA with ${ }^{32}$ P-labeled EHV-3 DNA fragment clones. EHV-3 restriction enzyme fragments present as insertions in plasmid cloning vectors were labeled with ${ }^{32} \mathrm{P}$ by nick translation and hybridized with EHV-1 restriction enzyme $B a m H I(B), B g l I I(B g), E c o R I(E)$, and $X b a I$ (X) digests bound to filters. The EHV-3 fragment clone used as the source for the probe is indicated at the top of each filter.

the EHV-3 genome. The reason for this structural difference is at present unclear, but current efforts to finely map and subclone het region sequences may provide more insight into this genomic distinction. It is interesting that in several human herpesvirus systems (herpes simplex virus, cytomegalovirus, and Epstein-Barr virus) various investigators have localized areas of heterogeneity to genomic termini and the junction between the long and short components, regions which have been shown to be involved in genomic replication, circularization, cleavage, encapsidation, and isomerization $(9,16,18-20,37,41,43)$. Whether het region sequences serve similar functions for the EHVs remains to be discovered. Second, EHV-1 BamHI fragment B shows significant homology to colinear fragments within the EHV-3 genome. BamHI fragment B spans the EHV-1 DNA regions which has been shown to be integrated in hamster embryo cells transformed with UV-inactivated EHV-1 (31), and the results of preliminary studies suggest that this EHV-1 fragment may detect cross-hybridizing viral sequences in hamster embryo cells transformed by EHV-3. Third, substantial homology exists between EHV-1 inverted repeat sequences and the corresponding repeat sequences in the EHV-3 genome. This is of interest because recent transcriptional studies have indicated that one major immediate early (alpha) EHV-1 transcript arises from the inverted repeats (W. L. Gray, R. P. Baumann, A. T. Robertson, G. B. Caughman, D. J. O'Callaghan, and J. Staczek, submitted for publication). Subclones of the EHV-1 inverted repeat which hybridize specifically to immediate early transcripts have been developed. These subclones are currently being used to probe EHV-3 DNA to determine whether homologous DNA sequences can be localized to defined DNA regions within the inverted repeats known to encode EHV-1 transcripts. Finally, no homology between EHV-1 and EHV-3 $\mathrm{U}_{\mathrm{s}}$ sequences could be detected under the stringent hybridization conditions used in these studies. Why this region alone should be less conserved than other genomic areas is uncertain, but studies on pseudorabies virus $(17,27)$ and varicellazoster virus (10), which are herpesviruses with a two-isomer type of structure similar to that of EHV-1 and EHV-3, have indicated that coding sequences for important viral glycoproteins are localized within the $U_{s}$ regions of these two viruses. Perhaps the EHV-1 and EHV-3 $U_{s}$ regions encode protein products (such as surface glycoproteins) which im- 
Alignment of EHV-1 and EHV-3 Homologous DNA Soquences

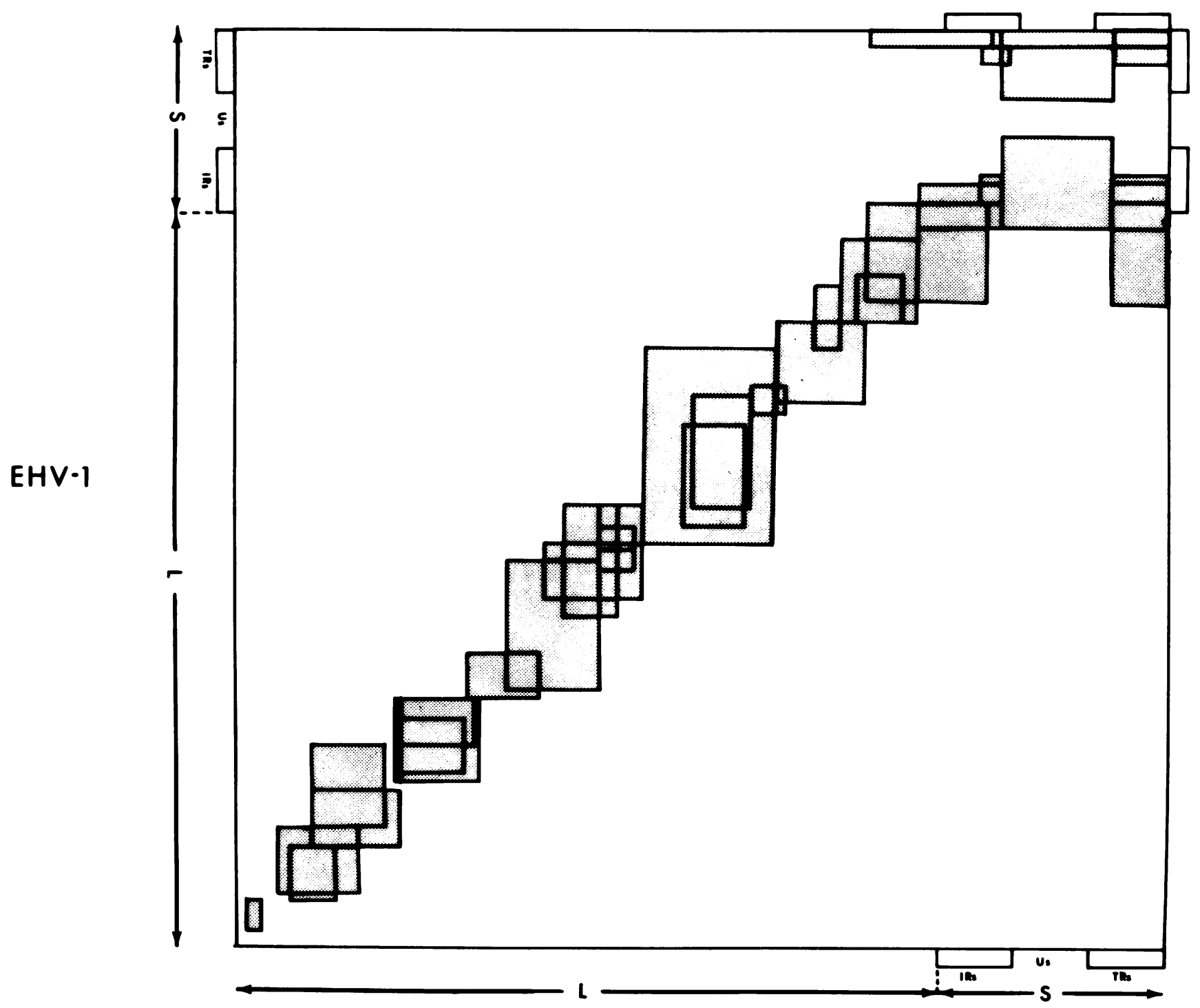

EHV-3

FIG. 5. Schematic diagram summarizing the relative regions of homology between the EHV-1 and EHV-3 genomes. The boxed areas indicate locations where cross-homology has been demonstrated by Southern blot hybridization. Vertical axis, EHV-1 genome; horizontal axis, EHV-3 genome. IRs, Inverted repeat sequences; TRs, terminal repeat sequences; L, long region; S, short region.

part some of the differential properties, such as serological type specificity, which serve to distinguish these two viruses.

Recently, Southern blot hybridization studies in which our library of cloned EHV-1 restriction enzyme fragments was used revealed that a refinement in the restriction endonuclease map of the EHV-1 genome was necessary. Specifically, DNA sequences between 0.20 and 0.70 map units were found to be inverted in the original EHV-1 map when they were compared with their actual configuration in the EHV-1 genome. This correction has been incorporated into the EHV-1 map shown in Fig. 1.
EHV-1 and EHV-3 are the etiologic agents of different diseases in horses and are serologically distinct in that they are not cross-neutralized. However, EHV-1 and EHV-3 have several properties in common, including a two-isomer genomic structure, the ability to oncogenically transform hamster embryo cells following abortive viral infection, and, as demonstrated here, widely dispersed colinear genomic homology. This study should serve as the basis for future investigations to determine whether functional similarities exist at the protein level comparable to the observed DNA sequence homology between the EHV-1 and EHV-3 genomes. 


\section{ACKNOWLEDGMENTS}

We thank Angela Houston and Cynthia Harrison for typing the manuscript and Joe Colacino for helpful suggestions.

Support for this investigation was obtained from Public Health Service research grants AI 22001 and AI 21996 from the National Institutes of Health and from a Grayson Foundation research grant.

\section{LITERATURE CITED}

1. Atherton, S. S., D. C. Sullivan, S. A. Dauenhauer, W. T. Ruyechan, and D. J. O'Callaghan. 1982. Properties of the genome of equine herpesvirus type 3. Virology 120:18-32.

2. Baumann, R. P., S. A. Dauenhauer, G. B. Caughman, J. Staczek, and D. J. O'Callaghan. 1984. Structure and genetic complexiy of the genomes of herpesvirus defective-interfering particles associated with oncogenic transformation and persistent infection. J. Virol. 50:13-21.

3. Benson, S. A. 1984. A rapid procedure for isolation of DNA fragments from agarose gels. Biotechniques March/April:67-68.

4. Bryans, J. T., and G. P. Allen. 1973. In vitro studies of equine coital exanthema virus, p. 322-336. In J. T. Bryans and $\mathrm{H}$. Gerber (ed.), Proceedings of the 3rd International Conference on Equine Infectious Disease. S. Karger, Basel.

5. Campbell, D. E., M. C. Kemp, M. L. Perdue, C. C. Randall, and G. A. Gentry. 1976. Equine herpesvirus in vivo: cyclic production of a DNA density variant with repetitive sequences. Virology 69:737-750.

6. Caughman, G. B., J. Staczek, and D. J. O'Callaghan. 1985. Equine herpesvirus type 1 infected cell polypeptides: evidence for immediate early/early/late regulation of viral gene expression. Virology 145:49-61.

7. Chang, C. Y., and S. N. Cohen. 1978. Construction and characterization of amplifiable multicopy DNA cloning vehicles derived from the P15A cryptic miniplasmid. J. Bacteriol. 134: 1141-1156.

8. Dauenhauer, S. A., R. A. Robinson, and D. J. O'Callaghan. 1982. Chronic production of defective-interfering particles by hamster embryo cultures of herpesvirus persistently infected and oncogenically transformed cells. J. Gen. Virol. 60:1-14.

9. Davison, A. J., and N. M. Wilkie. 1981. Nucleotide sequences of the joint between the $\mathrm{L}$ and $\mathrm{S}$ segments of herpes simplex virus types 1 and 2. J. Gen. Virol. 55:315-331.

10. Ellis, R. W., P. M. Keller, R. S. Lowe, and R. A. Ziuin. 1985. Use of a bacterial expression vector to map the varicella-zoster virus major glycoprotein gene, gC. J. Virol. 52:81-88.

11. Henry, B. E., W. W. Newcomb, and D. J. O'Callaghan. 1979 Biological and biochemical properties of defective interfering particles of equine herpesvirus type 1. Virology 92:495-506.

12. Henry, B. E., W. W. Newcomb, and D. J. O'Callaghan. 1980. Alterations in viral protein synthesis and capsid production in infection with DI particles of herpesviruses. J. Gen. Virol. 47: 343-353.

13. Henry, B. E., R. A. Robinson, S. A. Dauenhauer, S. S. Atherton, G. S. Hayward, and D. J. O'Callaghan. 1981. Structure of the genome of equine herpesvirus type 1. Virology 115:97-114.

14. Holmes, D. S., and M. Quigley. 1981. A rapid boiling method for the preparation of bacterial plasmids. Anal. Biochem. 114: 193-200.

15. Howley, P. M., M. A. Israel, M. F. Law, and M. A. Martin. 1979. A rapid method for detecting and mapping homology between heterologous DNAs. J. Biol. Chem. 254:4876-4883.

16. Locker, H., and N. Frenkel. 1979. BamI, KpnI, and SalI restriction enzyme maps of the DNAs of herpes simplex virus strains Justin and F: occurrence of heterogeneities in defined regions of the viral DNA. J. Virol. 32:429-441.

17. Mettenleiter, T. C., N. Lukacs, and H. J. Rziha. 1985. Mapping of the structural gene of pseudorabies virus glycoprotein A and identification of two non-glycosylated precursor polypeptides. J. Virol. 52:52-57.

18. Miller, G., L. Heston, and J. Countryman. 1985. P3HR-1 Epstein-Barr virus with heterogeneous DNA is an independent replicon maintained by cell-to-cell spread. J. Virol. 53:45-52.

19. Mocarski, E. S., and B. Roizman. 1981. Site-specific inversion sequence of the herpes simplex virus genome: domain and structural features. Proc. Natl. Acad. Sci. USA 78:7047-7051.

20. Mocarski, E. S., and B. Roizman. 1982. Structure and role of the herpes simplex virus DNA termini in inversion, circularization and generation of virion DNA. Cell 31:89-97.

21. O'Callaghan, D. J., G. P. Allen, and C. C. Randall. 1978. The equine herpesviruses, p. 1-32. In J. T. Bryan and H. Gerber (ed.), Equine infectious diseases, vol. 4. Veterinary Publications, Princeton, N.J.

22. O'Callaghan, D. J., W. P. Cheevers, G. A. Gentry, and C. C. Randall. 1968. Kinetics of cellular and viral DNA synthesis in equine abortion (herpes) virus infection of L-M cells. Virology 36:104-114.

23. O'Callaghan, D. J., G. A. Gentry, and C. C. Randall. 1983. The equine herpesviruses, p. 215-318. In B. Roizman (ed.), The Herpesviruses, vol. 2. Comprehensive virology, series 2. Plenum Publishing Corp., New York.

24. O'Callaghan, D. J., B. E. Henry, J. H. Wharton, S. A Dauenhauer, R. B. Vance, J. Staczek, and R. A. Robinson. 1981. Equine herpesviruses: biochemical studies on genomic structure, DI particles, onocgenic transformation, and persistent infection, p. 387-418. In Y. Becker (ed.), Developments in molecular virology, vol. 1. Herpesvirus DNA. Martinum Nijhoff, The Hague, The Netherlands

25. O'Callaghan, D. J., D. C. Sullivan, R. P. Baumann, G. B. Caughman, C. C. Flowers, A. T. Robertson, and J. Staczek. 1984. Genomes of the equine herpesviruses: molecular structure, regions of homology and DNA sequences associated with transformation. UCLA Symp. Mol. Cell. Biol. 21:507-525.

26. Perdue, M. L., M. C. Kemp, C. C. Randall, and D. J. O'Callaghan. 1974. Studies of the molecular anatomy of the L-M cell strain of equine herpesvirus type 1: proteins of the nucleocapsid and intact virion. Virology 59:210-216.

27. Rea, T. J., J. G. Timmins, G. W. Long, and L. E. Post. 1985. Mapping and sequence of the gene for the pseudorabies virus glycoprotein which accumulates in the medium of infected cells. J. Virol. 53:21-29.

28. Rigby, P. W., M. Dieckmann, C. Rhodes, and P. Berg. 1977. Labeling deoxyribonucleic acid to high specific activity in vitro by nick translation with DNA polmerase I. J. Mol. Biol. 113: 237-251.

29. Robinson, R. A., B. E. Henry, R. G. Duff, and D. J. O'Callaghan. 1980. Oncogenic transformation by equine herpesviruses (EHV). I. Properties of hamster embryo cells transformed by UV-irradiated EHV-1. Virology 101:335-362.

30. Robinson, R. A., and D. J. O'Callaghan. 1981. The organization of integrated herpesvirus DNA sequences in equine herpesvirus type 1 transformed and tumor cells, p. 419-436. In Y. Becker (ed.), Developments in molecular virology, vol. 1. Herpesvirus DNA. Martinum Nihjoff, The Hague, The Netherlands.

31. Robinson, R. A., and D. J. O'Callaghan. 1983. A specific viral DNA sequence is stably integrated in herpesvirus oncogenically transformed cells. Cell 32:569-578.

32. Robinson, R. A., P. W. Tucker, S. A. Dauenhauer, and D. J. O'Callaghan. 1981. Molecular cloning of equine herpesvirus type 1 DNA: analysis of standard and defective viral genomes and viral sequences in oncogenically transformed cells. Proc. Natl. Acad. Sci. USA 78:6684-6688.

33. Robinson, R. A., R. B. Vance, and D. J. O'Callaghan. 1980 Oncogenic transformation by equine herpesviruses. II. Coestablishment of persistent infection and oncogenic transformation of hamster embryo cells by equine herpesvirus type 1 preparations enriched for defective interfering particles. J. Virol. 36:204 219.

34. Ruyechan, W. T., S. A. Dauenhauer, and D. J. O'Callaghan. 1982. Electron microscopic study of equine herpesvirus type DNA. J. Virol. 42:297-300.

35. Sharp, P. A., B. Sugden, and J. Sambrook. 1973. Detection of two restriction endonuclease activities in Haemophilus parainfluenzae using analytical agarose-ethidium bromide electrophoresis. Biochemistry 12:3055-3063.

36. Southern, E. M. 1975 . Detection of specific sequences among DNA fragments separated by gel electrophoresis. J. Mol. Biol. 
98:503-517.

37. Spaete, R. R., and N. Frenkel. 1985 . The herpes simplex virus amplicon: analyses of cis-acting replication functions. Proc. Natl. Acad. Sci. USA 82:694-698.

38. Staczek, J., S. S. Atherton, and D. J. O'Callaghan. 1983. Genetic relatedness of the genomes of equine herpesvirus types 1,2 , and 3. J. Virol. 45:855-858.

39. Sullivan, D. C., S. S. Atherton, J. Staczek, and D. J. O'Callaghan. 1984. Structure of the genome of equine herpesvirus type 3. Virology 132:352-367.

40. Sutcliffe, J. G. 1979. Complete nucleotide sequence of the Escherichia coli plasmid pBR322. Cold. Spring Harbor Symp. Quant. Biol. 43:77-90.

41. Tamashiro, J. C., D. Filpula, T. Friedmann, and D. H. Spector.
1984. Structure of the heterogeneous L-S junction region of human cytomegalovirus strain AD169 DNA. J. Virol. 52:541548.

42. Vieira, J., and J. Messing. 1982. The pUC plasmids, an M13 $\mathrm{mp} 7$-derived system for insertion mutagenesis and sequencing with synthetic universal primers. Gene 19:259-268.

43. Vlazny, D. A., and N. Frenkel. 1981. Replication of herpes simplex virus DNA: localization of replication recognition signals with defective virus genomes. Proc. Natl. Acad. Sci. USA 78:742-746.

44. Whalley, J. M., G. R. Robertson, and A. J. Davidson. 1981. Analyses of the genome of equine herpesvirus type 1: arrangement of cleavage for restriction endonucleases EcoRI, BglII and BamHI. J. Gen. Virol. 57:307-323. 